Kong. Res. J. 3(1) : 22-25, 2016

Kongunadu Arts and Science College, Coimbatore.

\title{
BRYOPHYTES, THE IGNORED MEDICINAL HERBALS OF THE BIOLOGICAL WORLD - A SEARCH AT NEYYAR WILDLIFE SANCTUARY, TRIVANDRUM, KERALA
}

\author{
Greeshma, G.M., Bosco Lawarence, G.S. Manoj and K. Murugan* \\ Plant Biochemistry and Molecular Biology Laboratory, Department of Botany, University College, \\ Thiruvananthapuram. \\ *E.mail: harimurukan@gmail.com
}

\begin{abstract}
Currently, the medicinal potential of bryophytes has received immense value in pharmaceutical industries and many phytochemicals have been isolated, characterized from this group. Native North Americans and Chinese are in forefront in bryological research compared to India. Traditional and ethnic uses of Indian bryophytes with description and illustration were seen in Hortus Malabaricus. Information about the medicinal use of bryophytes in terms of microbicidal, anti-inflammatory and antitumour are traced in developed countries. Despite, the long history of medicinal bryophytes used by tribal and local peoples their significant utilization in medicines is still scanty. Present report is an attempt to create awareness about this group of plants from Neyyar Wild Life sanctuary, Trivandrum, Kerala.
\end{abstract}

Keywords: Bryophytes, Kerala, Hortus malabaricus.

\section{INTRODUCTION}

Bryophytes are the ancient terrestrial green spore-forming small imaged plants with amphibian mode of life cycle. The evidence of similarity of the present-day liverworts with the first land plant fossil spores record almost 400 million years ago (Kaur et $a l ., 2010)$. They are categorized between thallophytes and the pteridophytes. The group comprises 14000 species of bryophyta, 6000 of liverworts, 300 hornworts and 7700 moss species (Asakawa, 2012; Meenu Krishnan et al., 2014).

Phytochemicals are secondary metabolites produced by the plants with diverse biological potentialities. Botanical products are gaining significance due to their microbicidal activity against pathogens. Ethnically, bryophytes have been trailed as medicinal in traditional healers. They are employed for treatment of many skin disorders and wounds. Diverse kinds of biological activities are reported from bryophytes (Asakawa, 2003). Traditionally, Chinese initiated this sort of works more than 400 years ago. For instance, Polytrichum and Fissidens species were used as diuretic and hair growth stimulating drugs in China (Asakawa, 2003). North American Indians used Polytrichum juniperinum, Bryum, Mnium and Philonotis mosses to heal burns, bruises and wounds (Ilhan et al., 2006). Many others show microbicidal effects against fungi and bacteria (Dülger et al., 2009). Liverwort like Marchantia exhibited antifungal, antibacterial and antitumour activity (Veljic et al., 2010). It has also been shown that Ptilidium pulcherrimum have antibacterial and antifungal activity (Pejin and Pristov, 2012; Veljic et al., 2010).

Flavonoids, phenolics, monoterpenes and sesquiterpenes were proven phytochemicals with medicinal potentialitiesetc. The documented bryophyte chemistry opens many avenues in the field of biological research that can be used to establish future medicine. Knowledge of the bryophyte chemistry has recently expanded at an logarithmic phase. For example 49 monoterpenes, 389 sesquiterpenes, 112 diterpenoids, 69 steroids and several other saponins from liverworts were reported by various bryologists. Despite that it was estimated that only $6 \%$ of the species have been investigated chemically. The limitations are difficulty of collecting sufficient pure plant material for chemical studies and its identification (Lubaina et al., 2014). Some complex lipids and fatty acids have been reported from the mosses which change in response to environmental conditions. Asakawa et al. (2012) have studied about 1000 liverworts species from different parts of the world with respect to their chemistry, pharmacology and application as cosmetics, medicinal or agricultural drugs. They suggested that most of the hepaticeae contain lipophilic mono-, sesqui-, diterpenoids, aromatic compounds (bibenzyls, benzoates, cinnamates, long chain alkyl phenols, naphthalenes, phthalides, isocoumarins), and acetogenins which constitute the oil bodies (Alam et al., 2012; Alam et al., 2015). The biological activities of bryophytes are mainly due to the presence of these compounds 
(Dulger et al., 2009; Huai et al., 2010). Some species of Hepaticae cause allergic contact dermatitis (Frullania sp.) and allelopathy. The allergy inducing substances are sesquiterpene lactones (+)frullanolide and (-)- frullanolide and their related $\alpha$ methyl- $\gamma$-butyrolactones which has been isolated from Frullania dilatata and F. tamarisii respectively. Frullanolide, the best known constituents but the related lactones, constunolide are also reported. The liverwoet Chiloscyphus pallescens proved to be of interest as it contained a large amount of sesquiterpenoid ketol, Chiloscypholone, whereas Conocephalum conicum contain large amount of conocephalenol. Xie and Lou (2009) reported sesquiterpenoids namely isobicyclogermacremal, lepidozenal and vitrenal from Lepidozia vitrea. The first representative of large group of aromatic and phenolic compounds of bibenzyls derivatives is lunularic acid isolated by Sabovljevic et al., (2001) from Lunularia cruciata. This compound was also reported from several other liverworts in small amounts.

Many bryophyte species in fact manufacture broad-range antibiotics and are employed in dressings, diapers production, and other human medicinal applications in various parts of the world such as Asia, Germany, Brazil, England, China, and India. Occurrence of unique odors is one such hint which confirmed the presence of exclusive and potentially pharmaceutically important chemicals in bryophytes. This is particularly spot on for liverworts e.g. Isotachis japonica, Geocalyx graveolens has a turpentine-like smell, Leptolejeunea and Moerckia are specifically aromatic,62 species of Solenostoma scent like carrots, Lophozia bicrenata has a pleasing odor, Conocephalum conicum scents like mushrooms and Plagiochila rutilans smells like mint due to numerous menthane monoterpenoids. These are basically a combination of many compounds, including monoterpene hydrocarbons such as $\alpha$-pinene, $\beta$-pinene, myrcene, alphaterpinene, camphene, sabinene, limonene, fatty acids, and methyl esters (benzyl benzoate, benzyl cinnamate, and -phenylethyl cinnamate) of low molecular weight.

Generally bryophytes are not infected by pathogens, insects, snails, slugs and mammals, however, studies on their chemical constituents have been limitted. Bryophytes are considered to be useless for human diets. Some of the isolated terpenoids from liverworts show characteristic scents, pungency and bitterness, allergenic contact dermatitis, cytotoxicity, anti-HIV inhibitory, antimicrobial, antifungal, insect antifeedant and mortality, nematocidal activity, superoxide anion radical release.

\section{MATERIALS AND METHODS}

Neyyar Wildlife Sanctuary in the southern state of Kerala in India is spread over the southeast corner of the Western Ghats, and covers a total area of $128 \mathrm{~km}^{2}$ ( $49 \mathrm{sq} \mathrm{mi}$ ). It is located between $77^{\circ} 8^{\prime}$ to $77^{\circ} 17^{\prime}$ East Longitude and $8^{\circ} 29^{\prime}$ to $8^{\circ} 37^{\prime}$ North Latitude, central location $8^{\circ} 33^{\prime} \mathrm{N} 77^{\circ} 12.5^{\prime} \mathrm{E}$. Although it was declared as a sanctuary in 1958, not much was done about wildlife conservation, until 1985, when a separate wildlife wing was set up and as a result, conservation efforts have gathered momentum. Summer temperature is around 35 degrees Celsius and the winter being around 16 degree Celsius. The average rainfall from the Southwest monsoon between May and July and the Northeast monsoon between October and November, is about $2800 \mathrm{~mm}$. The tourist season here is between the months of November and March. This is the drainage basin for the Neyyar River and its tributaries - Mullayar and Kallar. The towering peak of Agasthyamalai at an elevation of 1868 meters is a prominent landmark.

\subsection{Methodology}

Traditional knowledge of bryophytes in medicinal field was gathered mainly through individual interviews with selected informants using a semi-structured interview format from 2013 to 2015 (Huai et al., 2010). Interviews were largely conducted in local language with the help of a local translator and responses were recorded in English. During interview with each informant, information regarding the type of ailments managed by the ethnic group against the reported ailments, the plant parts used, ways of remedy preparations, route of administration, precautions if any and dosage was gathered. Ethnobotanical data related to habitat and abundance, threat and local marketability of claimed medicinal plants as well cultivation practice were also collected. The information was also discussed with different lada vaidhyan in the localities to validate the claims as far as possible. Specimens for most of the reported bryophytes were collected, dried, properly identified and authenticated with the reference herbarium from Department of Botany, University of Calicut. Voucher specimens are deposited at the Herbarium of University College, Trivandrum.

\section{RESULTS AND DISCUSSION}

The results show that 112 households were surveyed and provided 277 citations of medicinal 
bryophytes. The number of citations per household ranged from 1 to 12 . The 277 citations were identified 14 species of medicinal bryophytes distributed in 13 genera and 11 families (Table 1). The identity of the bryophytes related to medicinal potential was confirmed with the local inhabitants through oral interview and field survey with their full concern. The high usage among the people could be an indication of their abundance as it was witnessed during visits to the study sites that areas very close to houses were well covered with herbs. The study area remains humid for most months of the year creating a favorable condition for the growth of herbs. The common use of herbaceous medicinal plants was also reported in studies carried throughout the world. Marchantia polymorpha thallus resembles the liver so for curing liver ailments. It is commonly used to treat the jaundice of hepatitis and as an external cure to reduce inflammation and has gained the reputation of cooling and cleansing the liver. For curing leucorrhoea, thalli are chewed and the sap is swallowed. During diarrhoea, the leafy extract is administered daily thrice for three days and in abdominal diseases, leaf paste is administered orally twice in a day. The plants reported by the locals are employed for curing mist of their local ailments.

Rhodobryum giganteum, a traditional medicine for heart trouble. During menstrual pain, the leafy extract crushed with seven peppers is administered daily once for 4-5 days. The herb is eaten raw for heart problems, nervous prostration and cardio-vascular diseases and nervous tension. Fissidens asperisectus, a moss used as a bactericidal agent to treat sore throats. During fever, decoction of tender tips is administered daily twice; during paralysis, slightly warmed leaf decoction is poured over the affected area daily twice. To make bandages for dressing the wound this plant is commonly employed. Philonotis fontana is a wetland moss to relieve pain of burns. Mixture of the thallose liverwort Marchantia polymorpha with vegetable oils is used on bites, boils, burns, cuts, eczema, and wounds. During rheumatic pain, flower extract is administered daily once for a fortnight; similarly, the paste is also administered daily once for a month as general tonic; during insect bite, the leaf paste is applied over inflammated area. Soothing a wound of a different sort i.e., burned, to put on their heads to encourage hair growth. Riccardia is a thallose liverwort known for its antileukemic activity. During rheumatic swellings in cattle, slightly warmed leaf juice is used as a lotion. During stomachache, leaves crushed with peppers are taken orally. Leafy liverwort Barbula is active against human epidermoid carcinoma. For curing constipation in cattle, plant extract is administered twice or thrice daily. During menstrual pain, leaf extract is administered twice a day for three days; during intermittent fever, whole plant decoction is administered daily once for five days. Frullania species with both allergic and medicinal properties. In case of burning micturition, extract of aerial parts crushed with cumin seeds is taken; pus oozing in ears, aerial parts crushed with cumin seeds and sugar is administered. During ephemeral fever, paste prepared from whole plant crushed with turmeric and common salt is fermented in two litres of toddy for $12 \mathrm{~h}$, the fermented toddy is administered daily once for four days.

Table 1. Medicinal bryophytes along with their ethnic use

\begin{tabular}{|c|c|c|c|}
\hline Sl.No & Name & Family & Uses \\
\hline 1 & Bryum argentums & Bryaceae & $\begin{array}{l}\text { Extract to cure angina Can increase aorta } \\
\text { blood transit }\end{array}$ \\
\hline 2 & Dumortiera hirsute & Marchantiacea & Exhibits antileukemic/antimicrobial activity \\
\hline 3 & Frullania muscicola & Jubulaceae & Skin ailments \\
\hline 4 & Marchantia polymorphya & Marchantiacea & $\begin{array}{l}\text { Used as diuretics, for liverailments, insect } \\
\text { bites, boils and abscesses, treat pulmonary } \\
\text { tuberculosis; Used to cure cuts, poisonous } \\
\text { snake bites, burns, for cardiovascular } \\
\text { disease. To treat boils and abscess As a } \\
\text { source of antibiotic }\end{array}$ \\
\hline 5 & Marchantia sp. & Marchantiacea & $\begin{array}{l}\text { Used as diuretics, for liverailments, insect } \\
\text { bites, boils and abscesses, treat pulmonary } \\
\text { tuberculosis; Used to cure cuts, poisonous } \\
\text { snake bites, burns, for cardiovascular } \\
\text { disease To treat boils and abscess As a }\end{array}$ \\
\hline
\end{tabular}




$\begin{array}{lll}6 & \text { Pallavicinia lyellii } & \text { Pallaviciniaceae } \\ 7 & \text { Rhodobryum giganteum } & \text { Bryaceae } \\ 8 & \text { Barbula sp. } & \text { Potiaceae } \\ 9 & \text { Riccardia sp. } & \text { Aneuraceae } \\ 10 & \text { Thudium sp. } & \text { Thuidiaceae } \\ 11 & \text { Brachythecium sp. } & \text { Brachytheciaceae } \\ 12 & \text { Fissidens nobilis } & \text { Fissidentaceae } \\ 13 & \text { Philonotis } s p . & \text { Bartramiaceae } \\ 14 & \text { Riccia } s p . & \text { Marchantiaceae }\end{array}$

4. CONCLUSION

Bryophytes are source of novel interesting bioactive drugs. The majority of the phytochemicals reported in the bryophytes are lipophilic terpenoids (mono-, sesqui-, and diterpenoids) and fragrant compounds. Few of them are nitrogen- or sulfurcontaining compounds. It is remarkable that most of the sesqui- and diterpenoids reported in liverworts are the enantiomers of those reported in angiosperms. Mono- and sesquiterpenoids are very unusual in mosses and hornworts, however, di- and triterpenoids have been isolated from certain mosses. Hence, there is an insightful call for their proper assessment regarding their useful chemical constituents and activities. Kerala, being one of the main centers of bryo-diversity is still at the back in applied bryological research and therefore need some serious efforts.

\section{REFERENCES}

Afroz Alam, Vinay Shrama, K.K. Rawat and P.K. Verma, (2015). Bryophytes - The Ignored Medicinal Plants. SMU Med. J. 2(1).

Alam, A., S.C. Sharma and V. Sharma, (2012). In vitro antifungal efficacies of aqueous extract of Targionia hypophylla L. against growth of some pathogenic fungi Int. J. Ayurvedic Herbal Med. 2(2):229-233.

Asakawa, Y., (2012). Liverworts-Potential Source of Medicinal Compounds Asakawa, Med. Aromat. Pl. 1(3):1-2.

Dulger, B., N. Haciolu and G. Uyar, (2009). Evaluation of antimicrobial activity of some mosses from Turkey. Asian J. Chem. 21(5):4093-4096.

Huai, H., Q. Dong and A. Liu, (2010). Ethnomedicinal analysis of toxic plants from five ethnic groups source of antibiotic

$\begin{aligned} & \text { Treating cardiovascular problem and } \\ & \text { anti-hypoxia, }\end{aligned}$
nervous prostration,
antipyretic, diuretic and antihypertensive
Boiled as tea for treating fever and body
ache
Exhibits anti-leukemic activity
relief from stress
Relief from stress
Diuretics and hair growth stimulation tonic
Heal burns for adenopharyngitis,
antipyretic and antidotal
Liver disorders
in China. Ethnobot. Res. Appl. 8:169-179.

Ilhan, S., F. Savaroglu, F. Colak, C. Iscen and F. Erdemgil, (2006). Antimicrobial activity of Palustriella commutata (Hedw.) Ochyra extract (Bryophyta). Turk. J. Biol. 30:149-152.

Kaur, S., Anju Rao and S.S. Kumar, (2010). Study on some of the contents of some bryophytes-II. Musci 5(3):80-83.

Lubaina, A.S., D.P. Pradeep, J.M. Aswathy, Remya Krishnan, V.G. Meenu Krishnan and K. Murugan, (2014). Traditional knowledge of medicinal bryophytes by the Kani tribes of Agasthiyarmalai biosphere reserve, southern Western Ghats. Indo Am. J. Pharm. Res. 4(4):2116-2121.

Meenu Krishnan, V.G., D.P. Pradeep, J.M. Aswathy, Remya Krishnan, A.S. Lubaina and K. Murugan, (2014). Wonder herbals- bryophytes, of the Ponmudi hills, of southern Western Ghats: window into the need for conservation. World J. Pharm. Pharmaceu. Sci. 3(4):1548-1562.

Pejin, B. and J.B. Pristov, (2012). ABTS Cation scavenging activity and total phenolic content of three moss species. Hem. Ind. 66(5):723-726.

Sabovljevic, M., A. Bijelovic and D. Grubisic, (2001). Bryophytes as a potential source of medicinal compounds. Lekovite Sirovine 21:17-29.

Veljic, M., A. Ciric, M. Sokovic, P. Janackovic and P.D. Marin, (2010). Antibacterial and antifungal activity of the liverwort (Ptilidium pulcherrimum) methanol extract. Arch. Biol. Sci. 62(2):381-395.

Xie, C.F. and H.X. Lou, (2009). Secondary Metabolites in Bryophytes: An Ecological Aspect. Chem. Biodivers. 9:303-312. 